\title{
PENGARUH DESAIN PRODUK DAN LAYANAN PURNA JUAL TERHADAP KEPUTUSAN KONSUMEN MEMBELI SEPEDA MOTOR YAMAHA MEREK NEW V-IXION FI (Full Injection) \\ (Studi Pada Konsumen Sepeda Motor Yamaha Merek NEW V-IXION FI (Full Injection) di Adiguna Sakti Motor Pandaan)
}

Eko Agus Alfianto

Dosen Program Studi Ilmu Administrasi Niaga

\begin{abstract}
ABSTRAK
Keputusan pembelian merupakan keputusan konsumen untuk membeli suatu produk setelah sebelumnya memikirkan tentang layak tidaknya membeli produk itu dengan mempertimbangkan informasi - informasi yang ia ketahui dengan realita tentang produk itu setelah ia menyaksikannya. Oleh karena itu produsen harus mampu menciptakan suatu produk yang baik dan berkualitas serta menarik yang mampu menciptakan keinginan konsumen untuk mencoba membeli produk tersebut.

Berdasarkan penelitian yang dilakukan di Adiguna Sakti Motor Pandaan dengan responden yang berjumlah 50 orang, menggambarkan bahwa desain produk dan layanan purna jual secara simultan tidak mempunyai pengaruh terhadap keputusan pembelian sepeda motor yamaha merek NEW V-IXION FI (Full Injection). Sedangkan secara parsial hanya layanan purna jual yang mempunyai pengaruh signifikan terhadap keputusan pembelian sepeda motor yamaha merek NEW VIXION FI (Full Injection). Untuk variable yang mempunyai pengaruh dominan terhadap keputusan pembelian sepeda motor yamaha merek NEW V-IXION FI (Full Injection) adalah layanan purna jual.

Adapun analisis yang digunakan adalah analisis regresi berganda, dan Uji T, sebelum dilakukan analisis regresi berganda diadakan Uji Validitas dan dan Realibilitas serta uji Asumsi Klasik untuk mengetahui Normalitas, Multikolinearitas dan heteroskedastisitas atau tidak.
\end{abstract}

Kata Kunci : Desain Produk, Layanan Purna Jual dan Keputusan Pembelian.

PENDAHULUAN

\section{Latar belakang}

Dalam setiap kebutuhan, konsumen akan melihat obyek-obyek yang melekat didalam sebuah produk, sebab setiap produk memiliki karakteistik yang berbeda satu samalainnya. Secara umum produk adalah apapun yang dapat ditawarkan untuk pasar yang dapat memenuhi keinginan atau kebutuhan tertentu. Produk-produk yang di pasarkan dapat berupa barang, jasa, pengalaman, peristiwa, orang, tempat, property, organisasi, informasi, dan ide (Kotler. 2005).

Salah satu konsep produksi yang cukup disukai oleh konsumen atas suatu produk adalah warna produk. Suatu produk akan lebih menarik jika memiliki warna yang beraneka macam karena warna memiliki gambaran bahwa konsumen mempunyai karakteristik yang berbeda-beda, dalam hal ini keputusan pembelian konsumen sepeda motor merek NEW V-IXION FI (Full Injection).

Keputusan pembelian konsumen juga dipengaruhi oleh layanan purna jual yang memiliki kerakteristik bermacam-macam salah satu bentuk layanan purna jual adalah jaminan yang diberlakukan pada barang yang telah dibeli konsumen. Produk yang dijamin itu dapat dikembalikan keperusahaan atau dikirim kepusat reparasi untuk perbaikan, penggantian, atau pengembalian uang, 
jaminan, baik dinyatakan dengan jelas atau tersirat, dapat dipaksakan pelunasannya secara hukum.

Jaminan (waranties) salah satu daya tarik layanan purna jual bagi setiap produk. Daya tarik tersebut dapat dijadikan sebagai salah satu pengambilan keputusan pembelian konsumen terhadap suatu produk. Salah satu faktor yang mempengaruhi keputusan pembelian adalah sosial, budaya, pribadi dan psikologi oleh karena itu perusahaan dalam menentukan produk serta strategi pemasarannya harus mampu membaca konsumen baik dari sisi sosial, budaya, pribadi ataupun psikologinya.

\section{Tujuan Penelitian}

a. Untuk mengetahui apakah desain produk $\left(\mathrm{X}_{1}\right)$ dan layanan purna jual $\left(\mathrm{X}_{2}\right)$ mempunyai pengaruh secara simultan terhadap keputusan pembelian (Y) konsumen sepeda motor yamaha merek NEW V-IXION FI (Full Injection)?

b. Untuk mengetahui apakah desain produk $\left(\mathrm{X}_{1}\right)$ dan layanan purna jual $\left(\mathrm{X}_{2}\right)$ mempunyai pengaruh secara parsial terhadap keputusan pembelian (Y) konsumen sepeda motor yamaha merek NEW V-IXION FI (Full Injection)

c. Untuk mengetahui apakah layanan purna jual $\left(\mathrm{X}_{2}\right)$ mempunyai pengaruh dominan daripada desain produk $\left(\mathrm{X}_{1}\right)$ terhadap keputusan pembelian (Y) konsumen sepeda motor yamaha merek NEW V-IXION FI (Full Injection)?

\section{KERANGKA TEORITIS DAN HIPOTESIS Pemasaran}

Pemasaran merupakan salah satu kegiatankegiatan pokok yang dilakukan oleh perusahaan dalam mempertahankan kelangsungan hidup perusahaan, berkembang untuk mendapatkan laba. Kegiatan pemasaran dirancang untuk memberi arti melayani dan memuaskan kebutuhan konsumen yang dilakukan dalam rangka mencapai tujuan perusahaan. Ada beberapa pendapat yang dikemukakan oleh beberapa ahli tentang pengertian pemasaran. Pemasaran adalah semua kegiatan usaha yang diperlukan untuk mengakibatkan terjadinya pemindahan kepemilikan barang atau jasa dan untuk menyelenggarakan distribusi fisiknya sejak dari produsen awal sampai konsumen akhir (Sigit, 2002). Pemasaran adalah memastikan bahwa barang dan jasa yang sesuai diproduksi. Berdasarkan definisi tersebut, pemasaran mencakup kegiatan sebagai berikut :

1. Mencari informasi yang berkaitan dengan keinginan, kebutuhan dan selera konsumen.

2. Merencanakan dan mengembangkan suatu produk atau jasa yang akan memenuhi keinginan dan kebutuhan yang disesuaikan dengan selera konsumen tersebut.

3. Memutuskan cara yang terbaik untuk menentukan harga, mempromosikan dan mendistribusikan barang dan jasa sehingga memudahkan konsumen dalam mencari informasi serta mendapatkan produk atau jasa yang ditawarkan sehingga mampu memenuhi 
kebutuhan konsumen secara cepat dan tepat.

\section{Desain Produk}

Masalah desain dari suatu produk telah menjadi salah satu faktor yang perlu mendapatkan perhatian serius dari manajemen khususnya team pengembangan produk baru, karena sasaran konsumen yang dituju tidak sedikit yang mulai mempersoalkan masalah desain suatu produk yang mampu memenuhi kebutuhan dan keinginan konsumen.

Menurut Kotler at all (2001), desain yang baik dapat menarik perhatian, meningkatkan kinerja produk, mengurangi biaya produksi dan memberi keunggulan bersaing yang kuat di pasar sasaran.Kotler (2005) mengemukakan bahwa desain produk adalah totalitas fitur yang mempengaruhi penampilan dan fungsi suatu produk tertentu menurut yang diisyaratkan dari segi kebutuhan pelanggan. Sementara itu, Hayes menyatakan bahwa desain produk merupakan factor yang akan sering memberikan kepada perusahaan sisi bersaingnya (Kotler, 2000).

Bagi Perusahaan, produk yang didesain dengan baik adalah produk yang mudah diproduksi dan didistribusikan. Sedangkan bagi pelanggan, produk yang didesain dengan baik adalah produk yang menyenangkan untuk dilihat dan mudah dibuka, dipasang digunakan, diperbaiki serta dibuang. Kotler (2005)mengemukakan terdapat 7 parameter desain produk yaitu

\section{Ciri-ciri}

Ciri-ciri adalah karakteristik yang mendukung fungsi dasar produk. Kinerja Ciri-ciri produk merupakan alat kompetitif untuk produk perusahaan yang terdiferensiasi. Beberapa perusahaan sangat inovatif dalam penambahan ciri-ciri baru ke produknya. satu dari faktor kunci keberhasilan perusahaan jepang adalah karena mereka secara terus menerus meningkatkan ciri-ciri tertentu pada produk seperti arloji, mobil, kalkulator, dll. Pengenalan ciri-ciri baru dinilai merupakan satu dari cara-cara yang sangat efektif dalam persaingan.

2. Kinerja

Kinerja mengacu kepada tingkat karakteristik utama produk pada saat beroperasi. Pembeli produk-produk mahal biasanya membandingkan kinerja (kenampakan/prestasi) dari merek-merek yang berbeda. Para pembeli biasanya rela membayar lebih untuk kinerja yang lebih baik sepanjang lebihnya harga tidak melebihi nilai yang dirasakan.

3. Mutu Kesesuaian

Yang dimaksud dengan penyesuaian adalah tingkat dimana desain produk dan karekteristik operasinya mendekati standar sasaran. Mutu kesesuaian adalah tingkat kesesuaian dan pemenuhan semua unit yang diproduksi terhadap spesifikasi sasaran yang dijanjikan. Hal ini disebut konformansi karena spesifikasinya.

4. Tahan Lama (Durability)

Daya tahan merupakan ukuran waktu operasi yang diharapkan dari suatu produk tertentu.

5. Tahan Uji (Reliabilitas) 
Reliabilitas adalah ukuran kemungkinan bahwa suatu produk tidak akan berfungsi salah atau rusak dalam suatu periode waktu tertentu. Pembeli rela membayar lebih untuk produkproduk dengan reputasi reliabilatas yang lebih tinggi. Mereka ingin menghindari biaya karena kerusakan dan waktu untuk reparasi.

6. Kemudahan Perbaikan (Repairability)

Kemudahan perbaikan adalah suatu ukuran kemudahan perbaikan suatu produk yang mengalami kegagalan fungsi atau kerusakankerusakan. Kemudahan perbaikan ideal akan ada jika pemakai dapat memperbaiki produk tersebut dengan biaya murah atau tanpa biaya dan tanpa memakan waktu terlalu lama.

7. Model (Style)

Model menggambarkan seberapa jauh suatu produk tampak dan berkenan bagi konsumen. Model memberi keunggulan ciri kekhususan produk yang sulit untuk ditiru.

Desain harus mempertimbangkan hal-hal tersebut dan mengikuti pepatah, "bentuk mengikuti fungsi”. Desainer harus menyesuaikan diri dengan beberapa ciri yang diinginkan. Kebanyakan tergantung kepada pemahaman cara pasar sasaran menerima produk dan mempertimbangkan segi manfaat dan biaya yang berbeda. Beberapa perusahaan kini menyadari pentingnya desain produk.

Dalam menetapkan desain produk, perusahaan harus terlebih dahulu menetapkan strategi desain produk. Menurut Tjiptono,(2001) terdapat tiga strategi desain produk. Strategi ini berkaitan dengan tingkat standarisasi produk. Perusahaan memiliki tiga pilihan strategi, yaitu produk standar, customizedproduct (produk disesuaikan dengan kebutuhan dan keinginan pelanggan tertentu), dan produk standar dengan modifikasi.

Desain produk adalah totalitas keistemewaan yang mempengaruhi penampilan dan fungsi suatu produk dari segi kebutuhan pelanggan. Dengan semakin ketatnya persaingan, desain akan menjadi salah satu cara yang paling ampuh untuk mendiferensiasikan dan memposisikan produk dan jasa perusahaan. Semua hal-hal yang telah disebutkan merupakan parameter-parameter desain. semuanya menegaskan betapa sukarnya tugas mendesain produk dengan segala keterbatasannya. Seorang desainer harus memahami berapa yang harus diinvestasikan dalam pengembangan ciri, kinerja, konformansi, daya tahan, kemudahan perbaikan, model dan sebagainya.

Dari sudut pandang perusahaan, sebuah produk yang didesain dengan baik akan mudah dibuat dan didistribusikan. Sedangkan dari sudut pandang konsumen, adalah produk yang menyenangkan untuk dilihat dan mudah dibuka, dipasang dan dipelajari cara penggunaanya, digunakan,diperbaiki, dan pada akhirnya dibuang.

Produsen berharap dengan adanya strategistrategi ini mampu meningkatan pertumbuhan, pangsa pasar, dan laba. Strategi produk standar dengan modifikasi juga memungkinkan 
perusahaan untuk melakukan hubungan yang erat dengan pasar dan memperoleh pengalaman dalam pengembangan standar produk yang baru.

Menurut Kotler (2000) desain produk mempunyai tujuan untuk membantu perusahaan dalam menciptakan dan mengembangkan sebuah produk atau untuk menjamin hasil produksi yang sesuai dengan keinginan pelanggan. Tujuan dari desain produk itu sendiri adalah:

1. Untuk menghasilkan produk yang berkualitas tinggi dan mempunyai nilai jual yang tinggi.

2. Untuk menghasilkan produk yang trend pada masanya.

3. Untuk membuat produk seekonomis mungkin dalam penggunaan bahan baku dan biaya-biaya dengan tanpa mengurangi nilai jual produk tersebut.

\section{Layanan Purna Jual}

Kotler (2000) menyatakan pelayanan adalah setiap tindakan yang dapat ditawarkan oleh suatu pihak kepada pihak lain, yang pada dasarnya tidak berwujud atau tidak mengakibatkan kepemilikan apapun. Layanan purna jual adalah berbagai macam layanan yang disediakan produsen atau perusahaan setelah produk dibeli oleh konsumen. Pelayanan purna jual merupakan suatu penyediaan jasa pendukung suatu produk begi pembeli atau konsumen pasca pembelian (Kotler 2002)

Para perusahaan akan selalu berusaha memberikan atribut produk yang terbaik pada produk mereka, layanan purna jual yang diberikan oleh produsen juga memegang peranan yang cukup penting dalam mendukung kesuksesan produk di pasar yang telah ditetapkan, khususnya pada produk tahan lama. Dengan adanya layanan purna jual, suatu produk akan memiliki daya tarik tersendiri di benak konsumen dan akan mempengaruhi minat beli konsumen dalam menentukan pilihan atau keputusan pembelian yang akan mereka ambil. Secara tidak langsung layanan purna jual yang ada dalam suatu produk juga menjadi media promosi perusahaan dalam menarik perhatian konsumen serta meminimalisir kehawatiran produsen dalam menentukan keputusan pembelian.

Menurut kotler (2002) Strategi yang bisa diterapkan dalam layanan purna jual adalah sebagai berikut :

1) Departemen pelanggan yang giat menerima permintaan, saran, dan bakan keluh kesah pelanggan

2) Departemen suku cadang atau jasa

Pelayanan dan kepuasan sesudah transaksi merupakan salah satu alasan mengapa konsumen tertarik untuk memilih suatu produk atau dengan kata lain, pelayanan purna jual menjadi daya tarik dari suatu produk dan layanan purna jual mempunyai sumbangan penting terhadap keberhasilan produk dalam bersaing di pasar. Layanan purna jual juga diperlukan oleh perusahaan untuk menjaga citra baik produk, merek dagang, dan citra perusahaan atau produsen. Dengan citra baik yang ada pada perusahaan, diharapkan konsumen yang merasa puas atas penggunaan produk dan layanan purna jual, bersedia untuk melakukan pembelian ulang dan menganjurkannya kepada keluarga dan teman untuk ikut membeli produk tersesbut. Tujuan dari pemberian layanan purna jual ini 
sendiri tidak lepas dari tujuan utama perusahaan yaitu meningkatkan minat beli konsumen terhadap produk perusahaan.

Tjiptono (2001) menjelaskan pada dasarnya ada tiga kunci untuk dapat memberikan layanan unggul kepada pelanggan:

1. Kemampuan memahami kebutuhan dan keinginan pelanggan

2. Pengembangan data base yang lebih akurat dari pesaing (mencakup data kebutuhan dan keinginan setiap segmen pelanggan dan perubahan kondisi persaingan)

3. Pemanfaatan informasi-informasi yang diperoleh dari riset pasar dalam suatu

\section{Keputusan Pembelian}

Perilaku konsumen adalah tindakantindakan yang dilakukan individu, kelompok atau organisasi yang berhubungan dengan proses pengambilan keputusan dalam mendapatkan, menggunakan barang-barang atau jasa ekonomis yang dapat dipengaruhi oleh lingkungan (Swastha, 2003). Perilaku konsumen akan menentukkan proses pengambilan keputusan dalam pembelian mereka, proses tersebut merupakan sebuah pendekatan penyesuaian masalah yang terdiri dari lima tahap yang dilakukan konsumen, kelima tahap tersebut adalah pengenalan masalah, pencarian informasi, penilaian alternatif, membuat keputusan, dan perilaku pasca pembelian (Kotler, 2004).

Keputusan pembelian adalah sebuah pendekatan penyelesaian masalah pada kegiatan manusia untuk membeli suatu barang atau jasa dalam memenuhi keinginan dan kebutuhannya yang terdiri dari pengenalan kebutuhan dan keinginan, pencarian informasi, evaluasi terhadap alternatif pembelian, keputusan pembelian dan tingkah laku setelah pembelian (Swastha, 1997). Menurut Swastha perilaku konsumen dapat diartikan sebagai suatu kegiatan-kegiatan individu yang secara langsung terlibat dalam mendapatkan serta menggunakan barang-barang dan jasa-jasa, termasuk di dalamnya proses pengambilan keputusan pada persiapan dan penerapan kegiatan (Swastha,2005).

Perilaku konsumen akan menentukan proses pengambilan keputusan dalam pembelian mereka. Proses tersebut merupakan sebuah pendekatan penyelesaian masalah yang terdiri atas beberapa tahap. Seluruh proses tersebut tidak selalu dilakukan oleh konsumen dalam pembeliannya. Pada umunya konsumen akan lebih mudah mengambil keputusan dalam pembelian ulang atau pembelian yang sifatnya terus menerus terhadap produk yang sama. Tahapan dalam proses keputusan pembelian menurut kotler,2007 sebagai berikut:

1. Pengenalan masalah

2. Pencarian informasi

3. Evaluasi alternatif

4. Keputusan pembelian

5. Perilaku pasca membeli

\section{Hipotesis Penelitian}

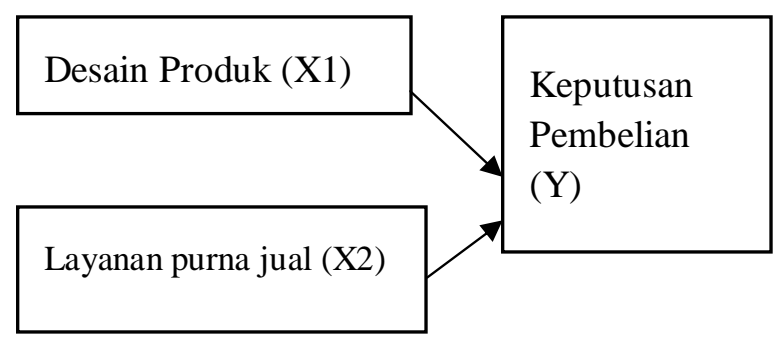




\section{Gambar 1 Model hipotesis Penelitian}

H1. :Diduga desain produk (X1) dan layanan purna jual (X2) mempunyai pengaruh secara simultan terhadap keputusan pembelian (Y)Sepeda Motor Yamaha Merek NEW VIXION FI (Full Injection)

H2. :Diduga desain produk (X1) dan layanan purna jual (X2) mempunyaipengaruh secara parsial terhadap keputusan pembelian (Y)Sepeda Motor Yamaha Merek NEW VIXION FI (Full Injection)

H3. :Diduga layanan purna jual (X2) mempunyai pengaruh dominan daripada desain produk (X1) terhadap keputusan pembelian (Y) konsumen sepeda motor yamaha merek NEW V-IXION FI (Full Injection)

\section{METODE PENELITIAN}

Jenis pendekatan penelitian yang digunakan dalam penelitian ini adalah menggunakan metode penelitian Kuantitatif dengan pendekatan analisis regresi berganda. Metode kuantitarif adalah metode penelitian yang datanya berbentuk angka-angka atau data kualitatif yang diangkakan (Sugiono, 2006). Lokasi untuk penelitian ini dilakukan di Adiguna Sakti Motor yang bertempat di JL. Raya Jetak NO. 192 Karangjati - Pandaan, untuk penelitian ini peneliti menggunakan sebanyak 50 responden. Adapun tekhnik yang digunakan adalah jenis penelitian asosiati (hubungan). Menurut Sugiono, (2006) penelitian asosiati merupakan jenis penelitian yang bertujuan untuk mengetahui hubungan antara dua variabel atau lebih. Bentuk hubungannya adalah hubungan kausal (sebab akibat).

\section{DEFINISI OPERASIONAL VARIABEL}

a. Desain Produk (X1) adalah totalitas fitur yang mempengaruhi penampilan dan fungsi suatu produk tertentu menurut yang diisyaratkan dari segi kebutuhan pelanggan. Variabel ini dapat diukur dengan menggunakan indikator sebagai berikut:

\section{Modifikasi}

2. Warna

3. Model

b. Layanan Purnajual (X2) merupakan pelayanan yang diberikan oleh perusahaan kepada konsumen pasca pembelian yang pada umumnya adalah masalah teknik, kemudahan mengganti orderdil yang rusak berbagai macam informasi dan yang lainnya. Variabel ini dapat diukur dengan indikator Garansi ,Kesediaan bengkel resmi yang mudah ditemui,Kualitas pelayanan yang baik, Kualitas ordeldil, Ordeldil mudah didapatkan, dan penanganan keluhan konsumen.

\section{c. Keputusan Konsumen (Y)}

Keputusan pembelian adalah serangkaian proses pengambilan keputusan yang dilakukan oleh konsumen (individu) dalam rangka memilih suatu barang atau jasa untuk dikonsumsi. Variabel ini dapat diukur dengan menggunakan indikator sebagai berikut:

1. Pilihan suatu merek 


\section{Pilihan suatu produk \\ 3. Pilihan suatu bentuk produk}

\section{HASIL PENELITIAN DAN PEMBAHASAN}

\section{Karakteristik Responden}

Dari 50 responden, jika didasarkan pada jenjang usia responden berusia antara 21 - 30 tahun sebanyak 25 orang (50\%), 31 - 40 tahun sebanyak 17orang (34\%) dan 41 - 50 tahun yaitu sebanyak 8orang (16\%). Dari tingkat pendidikan dengan tingkat pendidikan SD/MI sebanyak 5 orang $(10 \%), \mathrm{SMP} /$ sederajat sebanyak 7 orang (14\%), SMA/sederajat 20 orang (40\%) dan Perguruan tinggi sebanyak 18 orang (36\%). Jika dari tingkat pekerjaan, responden dengan pekerjaan wirausaha sebanyak 22 orang (44\%), PNS/BUMN sebanyak 6 orang (12\%), pegawai suwasta sebanyak 14orang (28\%) dan petani sebanyak 8 orang (16\%). Sedangkan dari tingkat pendapatan , responden dengan pendapatan kurang dari Rp. 2.000.000 sebanyak 23 orang (46\%), Rp. 2000.000 s.d Rp. 3000.000 sebanyak 21 orang (42\%), Rp. 3000.000 s.d Rp. 4000.000 sebanyak 2orang (4\%) dan pendapatan lebih dari Rp. 4000.000 sebanyak 4 orang(8\%).

\section{Analisis Data}

\section{Analisis Data Deskriptif}

Analisis data deskriptif dinyatakan dalam hasil uji validitas dan reliabilitas yang dalam penelitian ini adalah menggunakanprogram SPSS lFor Windowdan rumus Cronbach's Alpha, instrumen penelitian yang didasarkan pada jawaban 50 responden menyatakan bahwa instrumen penelitian pada variabel desain produk dan layanan purna jual adalah sesuai dengan uji validitas dan reliabilitas serta dapat digunakan untuk pengukuran dalam rangka pengumpulan data. Adapun hasil pengujiannya semua item dinyatakan valid dan reliabel.

\section{Analisis Data Inferensial}

Analisis statistik inferensial yang digunakan adalah Analisis Regresi Berganda, Uji F (simultan), uji t (parsial). Analisis regresi linier berganda digunakan untuk mengetahui pengaruh desain produk $\left(\mathrm{X}_{1}\right)$ dan layanan purna jual $\left(\mathrm{X}_{2}\right)$ terhadap keputusan pembelian $(\mathrm{Y})$, pengolahan perhitungannya dengan SPSS for windows..Uji (F) digunakan untuk mengetahui apakah variabel independen Desain Produk dan $\mathrm{X}_{2}$. Layanan Purna Jual secara bersama berpengaruh signifikan terhadap variabel Keputusan Pembelian). Menggunakan $a=5 \%$ (singnifikansi $5 \%$ atau 0,05 ) atau tingkat kepercayaan $95 \%$. Dalam pengujian ini bisa menggunakan Program SPSS, Bila $F$ hitung > F tabel artinya variabel independen secara bersama-sama berpengaruh terhadap variabel dependen. Sedangkan Uji t dilakukan untuk melihat signifikansi dari pengaruh variabel desain produk dan layanan purna jual (X) secara parsial terhadap variabel keputusan pembelian (Y).

\section{Pembahasan}

Berdasarkan dari hasil analisis ini terbukti bahwa variabel desain produk $\left(\mathrm{X}_{1}\right)$ dan layanan purna jual $\left(\mathrm{X}_{2}\right)$ secara bersamaan (simultan) tidak mempunyai pengaruh yang signifikan terhadap variabel keputusan pembelian (Y) pada sepeda motor yamaha merek NEW V-IXION FI 
(Fullinjection) di Adiguna Sakti Motor Pandaan. Berdasarkan hasil perhitungan uji $t$ Variabel desain produk memiliki nilai $\mathrm{t}$ hitung $<\mathrm{t}$ tabel $(0,725<2,011)$. Hal ini menunjukkan bahwa desain produk $\left(\mathrm{X}_{1}\right)$ tidak mempunyai pengaruh secara parsial terhadap variabel keputusan pembelian sepeda motor yamaha merek NEW VIXION FI (Full Injection), sedangkan pada variabel layanan purna jual berdasarkan hasil perhitungan uji $\mathrm{t}$ memiliki nilai $\mathrm{t}$ hitung $>\mathrm{t}$ tabel $(2,140>2,011)$. Hal ini menunjukkan bahwa layanan purna jual yang mempunyai pengarush secara parsial terhadap variabel keputusan pembelian.Variabel yang paling dominan pengaruhnya terhadap keputusan pembelian adalah variable layanan purna jual $\left(\mathrm{X}_{2}\right)$ dengan nilai beta 0,296 dan nilai sumbangan efektif (SE) sebesar $1,27 \%$,

Pada penelitian ini desain produk mempunyai nilai positif tetapi tidak berpengaruh signifikan terhadap keputusan pembelian hal ini sesuai dengan pendapat Kotler dan Amstrong (2001) bahwasannya Desain produk yang baik dapat menarik pehatian untuk melakukan pembelian. Semakin baik desain produknya maka semakin besar minat konsumen untuk membeli produk tersebut. Desain produk tidak mempunyai pengaruh signifikan disebabkan karena persepsi konsumen terhadap desain produk sangat baik dan bagus dibuktikan dengan penyebarak kuesioner atas pernyataan desain yang meliputi "Perusahaan memodifikasi yamaha NEW V-IXION FI (Full Injection) sehingga mempunyai nilai tambah dan Memiliki karakteristik khusus, Desain prodak dan karakteristik operasionalnya mendekati standart sasaran, Modifikasi NEW V-IXION FI (Full
Injection) Memiliki kemudahan dalam perbaikan, NEW V-IXION FI (Full Injection) memiliki desain warna yang menarik, Bentuk NEW VIXION FI (Full Injection) memiliki nilai artistik (indah/bagus) dan Bentuk NEW V-IXION FI (Full Injection) mempunyai nilai kemudahan dan stabil dalam penggunaan" dibenarkan oleh responden dengan melihat hasil uji $\mathrm{t}<$ dari $\mathrm{t}$ tabel $(0,725<2,011)$ sehingga konsumen dalam menjatuhkan pilihan untuk membeli tidak terlalu berfikir desain dari Yamaha New V-ixion FI (Fullinjection)

Sedangkan layanan purna jual mempunyai nilai positif serta berpengaruh signifikan hal tersebut sesuai dengan teori yang dikemukakan oleh Basu Swastha (2002) bahwasannya keputusan pembelian seorang konsumen untuk menggunakan prodak merupakan suatu proses yang komplek dan dipengarui oleh berbagai faktor seperti keputusan tentang prodak, keputusan tentang merek, keputusan tentang waktu, keputusan tentang penjual, keputusan tentang jumlah, keputusan tentang harga, keputusan tentang layanan yang diberikan perusahaan dan hal ini juga didukung oleh pernyataan Guiltinan (1994) yang menjelaskan bahwa salah satu strategi untuk menarik minat beli konsumen dan mempertahankan pelanggan adalah dengan meningkatkan kepuasan akan prestasi produk yang salah satunya dapat dilakukan dengan memberikan informasi atau pelayanan tambahan yang akan membantu kearah pengguanaan produk secara tepat dan efektif, seperti : pelayanan, pemeliharaan, dan perbaikan.

Dalam penelitian ini layanan purna jual juga merupakan variabel independen yang mempunyai pengaruh dominan terhadap 
keputusan konsumen membeli sepeda motor yamaha merek NEW V-IXION FI (Full Injection), di buktikan dengan penyebarak kuesioner atas layanan purna jual yang meliputi "Perusahaan melindungi dan menjamin kondisi serta kinerja yamaha NEW V-IXION FI (Fullinjection), Bengkel resmi Yamaha NEW VIXION FI (Full Injection) mudah ditemui, Pegawainya ramah tamah, Perusahaan menjamin kualitas onderdil yamaha NEW V-IXION FI (Full Injection), Onderdil NEW V-IXION FI (Full Injection) Mudah didapat, Keluhan konsumen ditangani dengan cepat dan tepat" kurang memiliki respon yang positif tehadap konsumen dengan melihat hasil dari uji $\mathrm{t}>$ dari $\mathrm{t}$ tabel $(2,140>2,011)$ ditambah lagi banyaknya penyedia jasa perbaikan sepeda motor yang kurang pengalaman dalam memperbaiki sepeda motor dengan mesin injection. Sehingga konsumen dalam memutuskan pembelian sepeda motor yamaha merek NEW V-IXION FI (Full Injection) di Adiguna Sakti Motor lebih memikirkan layanan purna jual daripada desain produk.

Walaupun desain yamaha NEW VIXION FI (Full Injection) sudah bagus dan kehandalan layanan purna jualnya kurang begitu bagus, perusahaan harus tetap meningkatkan kualitas desain produk terutama layanan purna jualnya untuk mengantisipasi pesaing yang ada dan agar konsumen lebih loyal terhadap produkproduk yamaha.

\section{KESIMPULAN DAN SARAN}

\section{Kesimpulan}

Berdasarkan hasil analisis dan pembahasan mengenai pengaruh desain produk dan layanan purna jual terhadap keputusan konsumen dalam membeli sepeda motor yamaha merek NEW V-IXION FI (Full Injection) di Adiguna Sakti Motor, maka dapat ditarik kesimpulan sebagai berikut :

1. Desain produk dan layanan purna jual secara bersamaan (simultan) tidak mempunyai pengaruh yang signifikan terhadap keputusan pembelian sepeda motor yamaha merek NEW V-IXION FI (Full Injection)

2. Desain produk dan layanan purna jual secara parsial hanya layanan purna jual yang mempunyai pengaruh signifikan terhadap keputusan pemelian sepeda motor yamaha merek NEW V-IXION FI (Full Injection) Dari desain produk dan layanan purna jual yang mempunyai pengaruh dominan terhadap keputusan pembelian sepeda motor yamaha merek NEW V-IXION FI (FullInjection) adalah layanan purna jual.

\section{Saran}

Berdasarkan hasil penelitian kami di dealer Adiguna Sakti Motor Pandaan, kami merekomendasikan beberapa hal yang berkaitan dengan desain produk dan layanan purna jual dengan harapan rekomendasi kami ini bisa menjadi refrensi Adiguna Sakti Motor Pandaan khususnya dan umumnya bagi siapa saja yang membutuhkannya.

1. Pada penelitian ini desain produk secara parsial tidak begitu mempunya pengaruh 
signifikan

terhadap keputusan

pembelian. Oleh karena itu perusahaan harus mempertahankan persepsi konsumen atas desain produk dengan terus melakukan inovasi-inovasi yang dilandaskan kepada analisis sehingga hasil dari desain produknya sesuai dengan keinginan konsumen.

2. Layanan purna jual pada penelitian ini mempunyai pengaruh singnifikan dan merupakan veriabel independen yang mempunya pengaruh dominan terhadap keputusan pembelian. Hal ini menunjukkan bahwa layanan purna jual merupakan salah satu faktor utama yang menjadi pertimbangan konsumen dalam menetukan keputusan pembelian sehingga perusahaan harus lebih meningkatkan layanan purna jualnya.

\section{DAFTAR PUSTAKA}

Alma, Buchari. 2009. Manajemen Pemasaran dan Pemasaran Jas Edisi revisi. Bandung: Alfabeta

Anggipura, Marius. 2002. Dasar-dasar Pemasaran Edisi 2. Jakarta: PT Raja Grafindo Persada.

Arikunto, Suharsimi. 2002. Prosedur Penelitian Suatu Pendekatan Praktek Edisi Revisi II. Jakarta: Reneka Cipta

Basu Swastha dan Irawan. (2003). "Manajemen Pemasaran Modern”. (Edisi kedua). Cetakan ke sebelas. Yogyakarta : Liberty Offset.

Basu Swastha, (2005), Manajemen Penjualan, Cetakan ke-duabelas, Yogyakarta: Penerbit Liberty
Charles W. Lamb, Joseph F. Hair, Carl Mcdaniel. 2001. Pemasaran. Edisi Pertama, Jakarta: Salemba Empat,

Djaslim Saladin, 2003, manajemen Pemasaran Analisis, Perencanaan, Pelaksanaan, dan Pengendalian. Bandung : Linda Karya

Fuad Mas'ud. 2004, Survai Diagnosis Organisasional, Konsep dan Aplikasi, Semarang: Badan Penerbit UNDIP

Ghozali, Imam. 2001. Aplikasi Analisis Multivariate dengan program SPSS, Edisi kedua, Semarang: Badan Penerbit Universitas Diponegoro

Ghozali, Imam. 2006. Aplikasi Analisi Multivariate dengan Progam SPSS, Semarang: Universitas Diponegaro

Kotler, Philip. 2000. Manajemen Pemasaran. Jilid 2. Jakarta: Bumi Aksara

. 2002. Manajemen Pemasaran Edisi Milenium

Buku I dan II. Diterjemahkan oleh Hendra Teguh dkk, Jakarta: PT. Prehallindo.

.2004, manajemen Pemasaran, Edisi Millenium, Jakarta:PT. Prenhallinda.

. 2005. Manajamen Pemasaran, Jilid 1 dan 2. Jakarta: PT. Indeks Kelompok Gramedia.

Kotler, Phillip dan Gary Amstrong. (2001). Prinsip-Prinsip Pemasaran, jilid 2, edisi ke8, Jakarta: Penerbit Erlangga.

Mursid. 2003. Manajemen Pemasaran. Jakarta: Bumi Aksara.

Santoso, Singgih. 2007. Menguasai Statistik di Era Informasi dengan SPSS 15. Jakarta: PT Elex Media Komputindo

Sigit, Soehardi, 2002, Pemasaran Praktis, Edisi ketiga, Yogyakarta: BPFE.

Sugiyono.2004, Metode Penelitian Bisnis, Bandung: Alfabeta. 
.2001. Metode Penelitian Administrasi. Bandung: Alfabeta.

.2006 metode Penelitian Bisnis. Bandung:

Alfabeta.

.2008. Metode Penelitian kuantittif kualitatif dan

R\&D. Bandung: Alfabeta

Tjiptono Fandy, 2001, Strategi Pemasaran.

Yogyakarta: Andi.

Umar, Husein. 2001, Metodologi Penelitian

Aplikasi Dalam Pemasaran. Cetakan

Pertama, Jakarta: PT. Gramedia Pustaka

Utama.

. 2002, Metodologi Penelitian Aplikasi Dalam

Pemasaran. Cetakan Kedua, Jakarta: PT.

Gramedia Pustaka Utama. 
